\title{
Cyclic-AMP Response Element-Based Signaling Assays for Characterization of Trk Family Tyrosine Kinases Modulators
}

\author{
Jie Zhang Diana Chen Xiaohai Gong Huaiping Ling Guoming Zhang \\ Andrew Wood Julia Heinrich Seongeun Cho \\ Neuroscience Discovery Research, Wyeth Research, Princeton, N.J., USA
}

\section{Key Words}

Neurotrophins $\cdot$ Trk $\cdot$ Signaling $\cdot$ Reporter $\cdot$ Luciferase $\cdot$

Mitogen-activated protein kinases $\cdot$ Phosphorylation

\begin{abstract}
Neurotrophins (NTs) induce gene transcription by binding their high-affinity tropomyosin-related kinase (Trk) receptors and initiating intracellular signal transduction cascades. In particular, activation of the cyclic AMP response element (CRE) in the promoters of target genes serves as surrogate markers for Trk receptor activation as demonstrated in both in vivo and in vitro systems. We used a HEK293 cell line stably expressing a CRE-luciferase reporter gene to develop an assay for monitoring Trk activation in response to their cognate ligands. Using TrkB, we showed that the assay was sensitive to physiological concentrations of brain-derived neurotrophic factor (BDNF) and that the signal was sufficiently robust to be suitable for implementation in high-throughput format. Further characterization of the TrkB expressing stable cell lines showed high-affinity binding for BDNF, a high density of receptor expression, and supported BDNF-mediated phosphorylation signaling. Consistent with this, inhibitors of phosphatidylinositol 3-kinase and the phospholipase $C-\gamma$ pathways led to reduction of BDNF-mediated luciferase responses. In contrast, inhibitors of mitogen-activated protein kinase pathways further potentiated BDNF responses.
\end{abstract}

This assay was NT-Trk receptor pair-selective and shown to be further applicable to other Trk family members. This assay may be useful in screening compound libraries to identify Trk agonists, which may be applied towards discriminating between the activities of the different Trk receptor family members and the development of pharmacological drugs.

Copyright $\odot 2006$ S. Karger AG, Basel

\section{Introduction}

Neurotrophins (NTs) are large secreted peptides important for the development of the nervous system and for maintaining neuronal integrity and plasticity through adulthood. NTs constitute a family of four members that bind a set of multi-domain single transmembrane receptors: the low-affinity glycoprotein p75 receptor and a family of high-affinity tropomyosin receptor kinases (Trk) [1]. The p75 receptor binds all the NTs, and its physiological role is most clearly understood for its association with processes that lead to cell death and apoptosis [2]. The Trk receptors, in contrast, are selective for the different NTs and mediate cell survival processes [3]. The cognate NTs for the Trk receptors are nerve growth factor (NGF) for TrkA, brain-derived neurotrophic factor (BDNF) and NT4/ 5 for TrkB and NT3 for TrkC, although the latter also has a low affinity for TrkA and TrkB $[4,5]$.

\section{KARGER \\ Fax +4161306 1234 E-Mail karger@karger.ch} www.karger.com

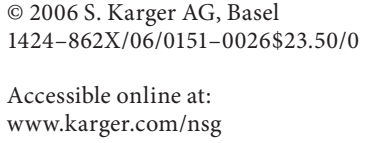

Dr. Seongeun Cho

Neuroscience Discovery Research

Wyeth Research, CN 8000

Princeton, NJ 08543-8000 (USA)

Tel. +1 732274 4469, Fax +1 732274 4755, E-Mail chos1@wyeth.com 
NTs bind and relay biological functions through homodimers or heterodimers of p75 and Trk receptors. The multiplicity of the NT system and their validated roles in neurodegenerative diseases has inspired considerable interest in identifying small non-peptide NT mimetics. Such compounds may provide reagents to probe how the different receptors influence cell fate and higher order functions, as well as drugs for pharmacological intervention.

NTs are peptides of approximately 120 amino acids that share about $50 \%$ homology. The active NT moiety is a pseudosymmetrical dimer in which the $\beta$-sheets of each monomer align to form a central core and the loops remain exposed [6]. On the other hand, the Trk receptors are multi-domain transmembrane proteins with approximately 800 amino acids. It has been shown that the ligand binding is promoted by two sets of contacts on the last domain of TrkB (D5/Ig2) [7]. One contact region is between the $\beta$-sheet of NT and loops at the C-terminal pole of Trk-D5/Ig2, and the second is between the N-terminal residue of NT and the face of one $\beta$-sheet of the Trk-D5/ Ig2. The first interaction involves 5 of the 9 residues of a domain, which is dubbed the 'conserved' patch for its high sequence homology among the NT. The second is with 3 of the 7 residues in a region that is more dissimilar among the NT, hence referred to as the 'specificity patch'. Specificity and high-affinity interactions between Trk receptors and NT ligands are also to be mediated by the loop regions of NTs, as shown by site-directed mutagenesis studies [8]. The paradigm where a few specific and spatially restricted residues are sufficient to generate a liganded receptor has spurred considerable effort in identifying Trk-specific agonists, leading to discovery of small molecules and peptidomimetic ligands $[6,9,10]$.

Binding of NTs to their cognate Trk receptor is believed to induce receptor dimerization and subsequent receptor protein conformational changes, which lead to the activation of intracellular tyrosine kinase domain, although pre-existing receptor oligomers have also been identified in a heterologous overexpression system [1113]. Phosphorylation of the tyrosine kinase activator domains causes the activation of multiple phosphorylationdependent signal transduction cascades, such as the Ras/ mitogen-activated protein kinase (MAPK), the phosphatidylinositol 3-kinase (PI3K)/Akt kinase pathway and the phospholipase C- $\gamma$ (PLC) pathway $[1,14-16]$. Several of these signal transduction cascades converge on transcriptional regulation of target genes by virtue of modulating the activity of a common transcription factor. One well-characterized enhancer is the cAMP response element (CRE), which is considered a key player in multiple neuronal processes that promote normal mammalian physiological and psychological well-being [17]. For example, CRE-induced gene transcription is crucial for BDNF-mediated long-term synaptic plasticity and CREB activation regulates the pro-survival effects of BDNF [18, 19]. Therefore, activation of CRE is indicative of many of the therapeutic benefits of BDNF activity.

Several assays have been reported in the pursuit of identifying activators of transmembrane receptors in general and Trk receptors in particular. These may include approaches that monitor ligand-promoted dimerization/oligomerization of receptors, transcriptional activity assays using either reporter genes or endogenous genes, and biochemical assays that assess protein phosphorylation [20]. Although phosphorylation analyses are the most proximal measure of receptor activation and hence likely to identify the least non-specific hits, they require multiple steps that are incompatible with highthroughput screening, such as immunopurification of receptors and phosphorylation of an exogenous substrate [21-23]. The assays to measure receptor dimerization are based on the general thought that receptor dimerization is a key step required for downstream signaling events. They rely on two-hybrid interaction of epitope-tagged receptor constructs, such as dihydrofolate reductase [24]. However, this approach also has limitations in that dimerization may be insufficient for receptor activation, preformed dimers may exist, and/or a conformational change in a receptor monomer may be sufficient to activate the receptor. In contrast, the tractability of transcriptional activation of target genes is historically well validated in the use of a luciferase reporter gene. For example, a small non-peptidyl molecule, SB-247464, was identified for granulocyte colony-stimulating factor (G-CSF) receptors using this approach [25]. However, in the case of $\operatorname{TrkB}$, a transcriptional assay with a robust signal has not been achieved in several reports, as exemplified by a 2 - to 3 -fold induction of luciferase gene by $100 \mathrm{ng} / \mathrm{ml} \mathrm{BDNF}$ in PC12 cells transiently transfected with TrkB [26]. Considering that all reported NT mimetics so far were identified by a rational design, selected from limited libraries of peptides or peptidomimetics mimicking the structure of NT at key interaction sites [9, 10,27], there is a great need for a new improved assay for discovery of small molecules with novel chemical properties [20].

In this report, we describe a development of CRE-luciferase reporter gene assay and its application towards quantitatively measuring the activities of Trk receptors. We initially focused on characterization of the TrkB system as a prototype of the NT receptors. The CRE-lucifer- 
ase-based TrkB assay represents a robust, sensitive, doseand time-dependent response that was specific to BDNF. BDNF binding could be competed by supplementing the media with a soluble extracellular domain of TrkB (TrkBFc) or with inhibitors of signal transduction pathways. In addition, activation of TrkB was confirmed by the autophosphorylation of key intracellular residues and intermolecular phosphorylation of key effector substrates. Furthermore, the utility of the system was extended to the NGF:TrkA pair and examined for its suitability as a high-throughput screen (HTS) to aid identification of small molecular weight NT mimetics.

\section{Materials and Methods}

\section{Transient and Stable Transfection}

HEK293 cells stably expressing the $3 \times$ CRE_luc plasmid (Mercury Signal System, Clontech) were seeded in $10-\mathrm{cm}^{2}$ plates at a density of $7 \times 10^{5}$ cells $/ \mathrm{ml}$ and the next day transfected with $5 \mu \mathrm{g}$ of a pcDNA3.1/hygromycin (Invitrogen, Carlsbad, Calif., USA) containing a Trk isotype using Lipofectamine 2000 Reagent (Invitrogen) according to the manufacturer's instructions. The day post-transfection the cells were reseeded into 96-well white opaque plates (Nunclon, Nunc) and assayed for expression of TrkB by the luciferase activity assay or divided into eight $10-\mathrm{cm}^{2}$ tissue culture plates at varying dilutions (1:20-1:80) for generation of stable cell lines. Cells plated at limiting dilutions were grown in standard media DMEM containing $10 \%$ fetal calf serum and $1 \%$ Pen/Strep, supplemented with $250 \mu \mathrm{g} / \mathrm{ml}$ geneticin/G418, $2 \mu \mathrm{g} / \mathrm{ml}$ puromycin and $350 \mu \mathrm{g} / \mathrm{ml}$ hygromycin until single colonies appear. Single colonies were picked by cloning cylinders, expanded, cryo-frozen for banking and screened for induction of luciferase responses following treatment with $100 \mathrm{ng} / \mathrm{ml}$ of BDNF or NGF for TrkB or TrkA, respectively. Clones with a minimum of 7-fold activities over the basal were further expanded and subject to full-dose response studies $(0.8-800 \mathrm{ng} / \mathrm{ml}$ of appropriate NTs). Selected clones were maintained in their standard selection media. The parental cell line is referred to as HEK-CRE and the different stable cell lines as HEK-CRE-Trk.

\section{Luciferase Activity Assay}

HEK-CRE-Trk or HEK-CRE cells were plated at 15,000 cells/ well in $100 \mu$ l growth medium in 96-well white opaque plates. The next day, the cells were treated with $10 \mu$ l of 10 -fold concentrated cognate NT solution (Peprotech) and/or testing reagents as indicated in the figures. Accumulation of luciferase activities was routinely measured $16 \mathrm{~h}$ post-treatments, or as indicated in the figures, with Promega Steady-Glo Assay kit according to the manufacturer's protocol (Promega). In brief, media was replaced with $100 \mu \mathrm{l} /$ well of PBS followed by $100 \mu \mathrm{l} /$ well of Steady-Glo Assay reagent; plates were sealed with TopSeal (PerkinElmer) and shaken on a Titer Plate Shaker (Lab line instruments) at a dial speed of 5 for $5 \mathrm{~min}$, and luminescence was detected in TopCount NXT v2.13 Instrument (Packard) as counts per second (CPS). Results are presented as CPS or increase over the basal activity as indicated in the figures.

\section{Receptor Saturation Binding Assay}

Saturation radioligand binding experiments using HEK-CRETrkB cells were conducted on both the membrane fraction and the intact cells. To prepare membranes, cells were washed with PBS, dissociated from tissue culture plates and centrifuged at $1,000 \mathrm{~g}$ for $10 \mathrm{~min}$. The pellet was resuspended in five volumes of ice-cold 50 mM Tris, pH 7.4, with 1 mM EDTA, homogenized with a Polytron and centrifuged at $20,000 \mathrm{~g}$ for $20 \mathrm{~min}$ at $4^{\circ} \mathrm{C}$; this process was repeated twice. The final membrane pellets were resuspended in a binding buffer (50 mM Tris, $\mathrm{pH} 7.4 ; 10 \mathrm{mM} \mathrm{MgSO}_{4}$; $0.5 \mathrm{~mm}$ EDTA) at a concentration of $2 \mathrm{mg} / \mathrm{ml}$ and aliquots were stored at $-80^{\circ} \mathrm{C}$ until use. Membranes were thawed on the day of the experiment and diluted to $1.5 \mathrm{mg} / \mathrm{ml}$ with the binding buffer and aliquots of $100 \mu \mathrm{l}$ were added to each well of 96-well GF/B flat-bottom plates (PerkinElmer) containing an incubation mixture consisting of $80 \mu \mathrm{l}$ of binding buffer and $20 \mu \mathrm{l}$ of [ $\left.{ }^{125} \mathrm{I}\right] \mathrm{BDNF}$ (spec. act. 2,200 Ci/mmol, PerkinElmer). The non-specific binding was measured by the addition of $740 \mathrm{nM}$ cold BDNF. Binding incubations proceeded at room temperature in the dark for $120 \mathrm{~min}$ and was terminated by filtration over a 96-well Unifilter followed by two washes with the binding buffer using Filtermate 196 Harvester (Packard). For the whole cell binding, HEK-CRETrkB cells were plated onto poly-D-lysine-coated 96-well tissue culture plates (BD Bioscience) at a density of $4 \times 10^{4}$ cells/well. After rinsing the cells 3 times with the binding buffer, aliquots of the incubation mixture were added to each well and the plates were incubated first at $37^{\circ} \mathrm{C}$ for $30 \mathrm{~min}$ and then at room temperature for another $30 \mathrm{~min}$. The binding reaction was stopped by aspiration of the incubation mixture and cells were lifted using a non-enzyme dissociation buffer (GibcoBRL). Cell suspensions were transferred to 96-well GF/B plates (PerkinElmer) and filtered over a 96-well Unifilter to capture the binding complex followed by two washes. The bound complexes caught on the filter disk obtained above from both the membrane preparation and intact cells were air-dried. To each well was added $40 \mu \mathrm{l}$ of Microscint ${ }^{\circledR}-20$ scintillant and plates were heat-sealed. Plates were counted in a TopCount NXT (Packard). Specific binding was the difference between total and non-specific binding and data was analyzed by non-linear regression using Prism 4.0 (GraphPad Software Inc.).

\section{Western Blot Analysis}

HEK-CRE-TrkB stable cells were seeded in 24-well tissue culture plates at $2 \times 10^{5}$ cells/well in a standard medium and the next day incubated in serum-free DMEM for 90 min prior to stimulation with a cognate ligand and/or compounds as indicated in the figures. Stimulation was terminated by removal of the medium, one wash with PBS and harvesting of the cells in $100 \mu \mathrm{l}$ of Laemmli sample buffer (Bio-Rad) preheated to $95^{\circ} \mathrm{C}$. The cell suspensions were filtered through QIAshredder columns (Qiagen) and $20 \mu \mathrm{l}$ of eluted samples were resolved on $4-12 \%$ Bis-Tris gels (Invitrogen) and processed for Western blot analysis using nitrocellulose filter membranes and semi-dry transfer apparatus (BioRad). Immunoblotting was carried out using appropriate primary antibodies (anti-TrkB (1:250, Santa Cruz, sc-8613); anti-PY490 phospho-Trk (1:100, Cell Signaling); anti-MAPK (1:5,000, Cell Signaling); anti-phospho-MAPK (1:2,000, Cell Signaling)), HRPconjugated secondary antibodies (Molecular Probes) and ECL Plus Kit (Amersham). For immunoprecipitation of phosphoTrkB, BDNF-treated HEK-CRE-TrkB cells were lysed in a stan- 
dard RIPA buffer with an addition of protease inhibitors (Roche Applied Science). Two micrograms of anti-TrkB antibody (Santa Cruz, sc-8316) was added to $1 \mathrm{mg}$ of lysate and the samples were incubated at $4{ }^{\circ} \mathrm{C}$ overnight on a rotator. The next day, $75 \mu \mathrm{l}$ of Protein A solution (Roche Applied Science) was added to the TrkB-antibody conjugate for additional incubation for $1 \mathrm{~h}$. The resulting immunoprecipitated pellets were washed 3 times with the RIPA lysis buffer and subjected to electrophoresis on a $4-12 \%$ NuPage Tris-glycine gel and probed by Western blotting using anti-phosphotyrosine antibody G410 (0.1 $\mu \mathrm{l} / \mathrm{ml}$, Upstate). The signal was detected using a HRP-coupled anti-mouse secondary antibody (1:10,000, Jackson Laboratories) and the bands were visualized by ECL (Amersham) and measured using a densitometer equipped with Quantity One (Bio-Rad).

\section{Results}

Evaluation of Luciferase Responses in a Transient Transfection System

Experiments were performed to determine if BDNF treatment would lead to the accumulation of luciferase protein in HEK-CRE cells transiently expressing TrkB, according to the scheme diagrammed in figure 1 . The results showed that transfection of $\operatorname{TrkB}$ was essential for detection of the luciferase signal in response to BDNF treatment (fig. 2a). The luciferase signal from HEK-CRETrkB cells, as compared to that from HEK-CRE cells transfected with vector or mock-treated, increased 10fold over basal activity $(\mathrm{p}<0.001)$. The assay system demonstrated a BDNF dose-dependent (fig. 2b) and time-dependent (fig. 2c) accumulation of luciferase signal. Doseresponse evaluation determined the $\mathrm{EC}_{50}$ of $\mathrm{BDNF}$ to be $34.64 \mathrm{ng} / \mathrm{ml}$ (1.28 nM) (fig. 2b), which concurs with published values for physiological concentration of BDNFmediated actions $[28,29]$. These results demonstrated that the assay was a robust and sensitive functional reporter for TrkB. After BDNF treatment, a lag period of up to $4 \mathrm{~h}$ was followed by an increase in luciferase signal form HEK-CRE-TrkB cells, as compared to empty vector transfected HEK-CRE cells, which showed no increase (fig. 2c). From these results, $16 \mathrm{~h}$ treatment with BDNF was selected as a standard time for subsequent experiments.

The transient transfection approach resulted in variable transfection efficiencies that could introduce variability in measurement outcome. To circumvent this, we transfected a large batch of HEK-CRE cells and froze them in aliquots $24 \mathrm{~h}$ post-transfection for assays at later dates. Vials were kept frozen for a minimum of 3 days and up to 7 days, after which cells were thawed directly in 96well assay plates to assess the effect of freeze and thaw on

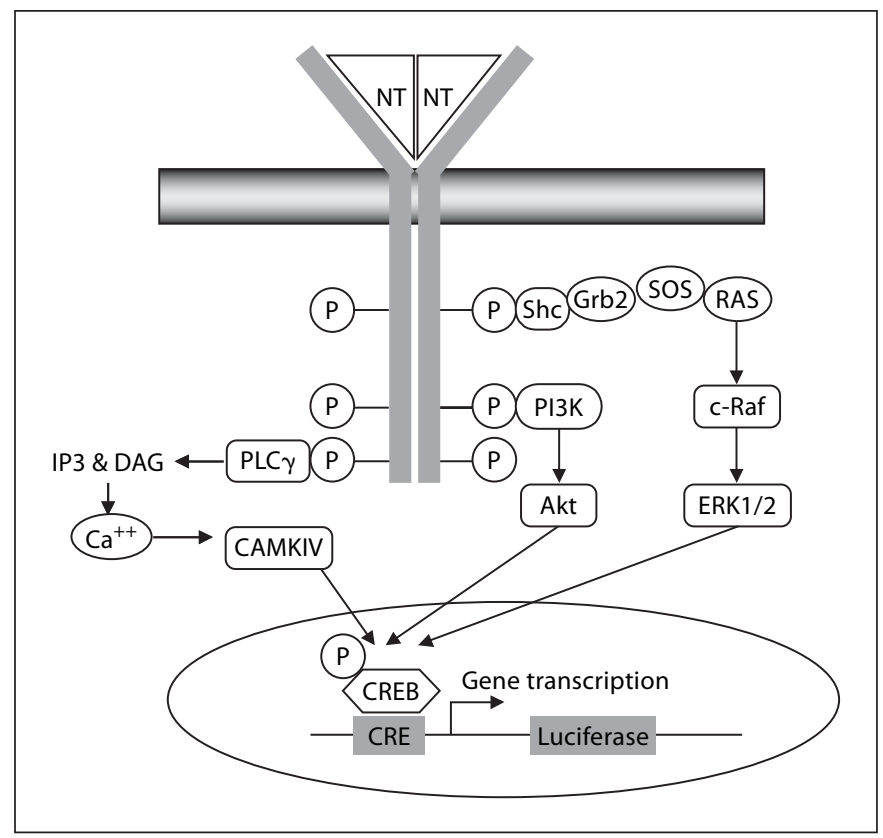

Fig. 1. NT-liganded Trk monitored indirectly by transcriptional induction of a CRE-regulated luciferase reporter gene. Activation and autophosphorylation of Trk is coupled to a number of kinase cascades including Shc-MAPK, PI3K/AKT and PLC- $\gamma$, leading to the activation of CRE-regulated gene expression. HEK293 cells stably expressing a reporter cassette consisting of three CRE enhancers upstream of a promoter and luciferase reporter gene (HEK-CRE) couples activation of Trk to detection of luciferase protein accumulation, which can be detected by Promega SteadyGlo Assay kit.

transient expression of $\operatorname{TrkB}$ and their luciferase signal response. Cells were treated with BDNF either on the same day $6 \mathrm{~h}$ after the plating, or the next day approximately at $30 \mathrm{~h}$, and the luciferase activity was measured after an additional incubation period of $16 \mathrm{~h}$. As shown in figure $2 \mathrm{~d}$, at as early as $6 \mathrm{~h}$ post-thawing a modest increase in BDNF-induced luciferase activity was detectable in a TrkB-specific manner. The signal window was dramatically increased after a longer recovery period as demonstrated by $\sim 7$-fold change at $30 \mathrm{~h}$ post-thawing/replating. These results validated the assay and the use of the transient expression approach for moderate and routine throughput screening requirements.

\section{Selection of HEK-CRE-TrkB Stable Cell Lines}

Our typical high-throughput screening campaigns require cell numbers that would be better served by using stable rather than transient cell lines. We therefore made HEK-CRE-TrkB stable cell lines. Examples of the response 


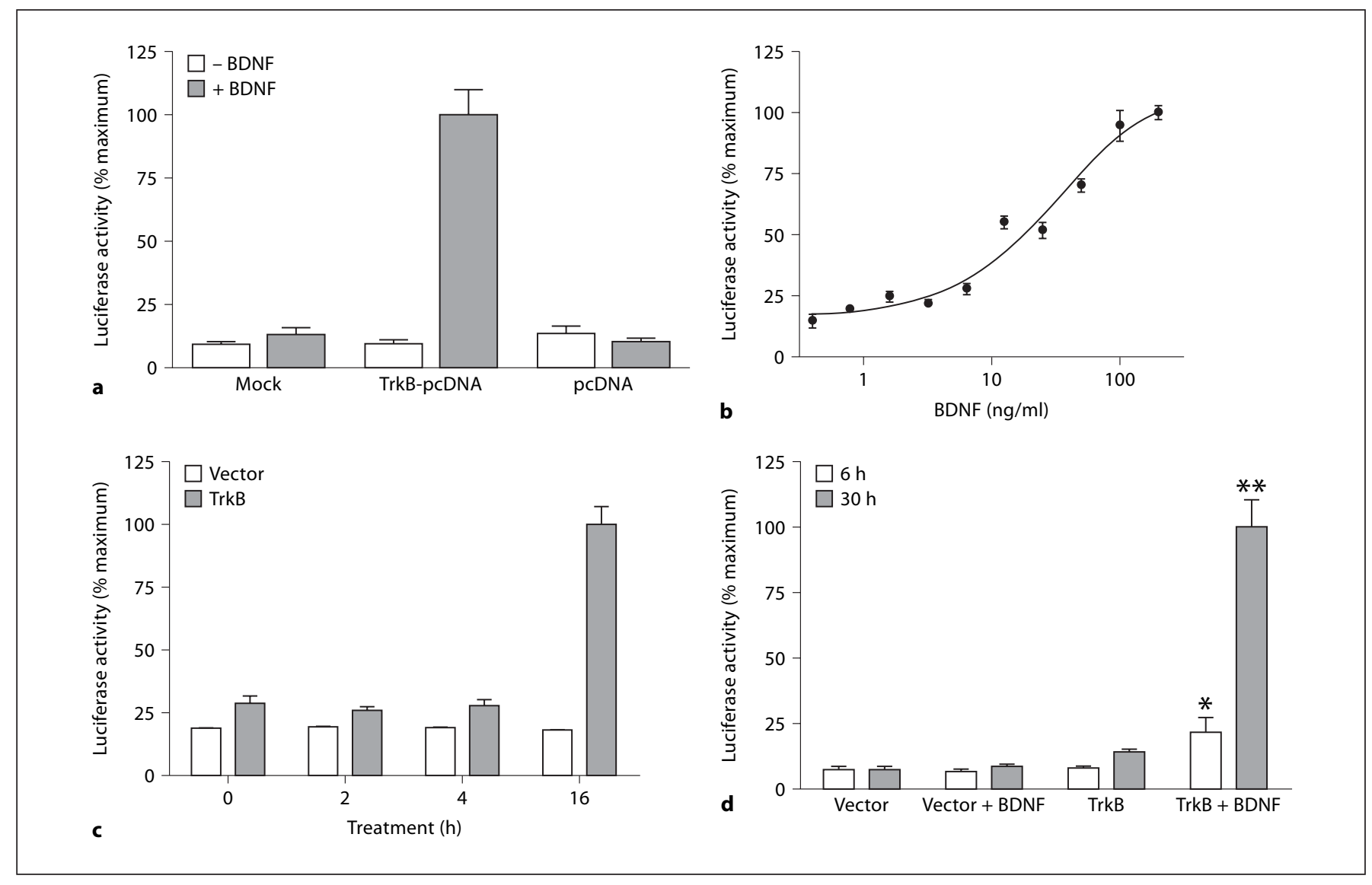

Fig. 2. Evaluation of the luciferase reporter activities in HEK-CRE transiently expressing TrkB. a Expression of TrkB selectively induces the luciferase activities. HEK-CRE cells were transiently transfected with either a TrkB plasmid or an empty vector or mock-treated. $24 \mathrm{~h}$ later, transfected cells were transferred to 96well assay plates and cultured in growth media in the absence or presence of BDNF $(100 \mathrm{ng} / \mathrm{ml})$. The luciferase activities were measured following overnight incubation. b BDNF dose-response measured at $16 \mathrm{~h}$ after BDNF addition to the growth medium to HEK-CRE-TrkB cells. An $\mathrm{EC}_{50}$ of BDNF was determined to be $34.64 \mathrm{ng} / \mathrm{ml}(1.28 \mathrm{nM})$. c Time-points after addition of BDNF in the HEK-CRE transfected cells when luciferase accumulations were measured. d Recovery of the luciferase responsiveness from cryopreseveration. HEK-CRE cells in T75 flasks were transfected with either a TrkB plasmid or a vector and frozen in aliquots $24 \mathrm{~h}$ post-transfection in 5-6 cryovials. 3-7 days later, cells were thawed, seeded on assay plates, and BDNF was added either 6 or $30 \mathrm{~h}$ post-plating. $16 \mathrm{~h}$ post-BDNF treatment, the luciferase activity was measured as indicated in the Methods. TrkB-mediated signaling was fully recovered following freeze and thaw, resulting in time-dependent induction of luciferase activities. ${ }^{*} \mathrm{p}<0.05$ and ${ }^{* *} \mathrm{p}<0.01$, compared with TrkB alone ( $\mathrm{t}$ test). from 11 clones in the absence and presence of BDNF treatment are illustrated in figure $3 \mathrm{a}$. Different clones showed different levels of basal luciferase activities, as well as diverse responsiveness to BDNF treatment, ranging from no to $\sim 7$-fold signal increase following BDNF treatment. Western blotting analysis (fig. 3b, and data not shown) confirmed the presence of TrkB in clones which showed BDNF-induced luciferase. We chose HEK-CRE-TrkB, clone 22, for additional characterization in this study. Clone 22 expressed a single major band of proteins recognized by a TrkB antibody that migrated at approximately
$140 \mathrm{kDa}$ (fig. 3b), which is consistent with the molecular weight of TrkB. Radioligand saturation binding assays with BDNF revealed an apparent dissociation constant $\left(\mathrm{K}_{\mathrm{d}}\right)$ of $425.1 \pm 168.7$ and $649.5 \pm 19.6 \mathrm{pM}$ in cell lysates and on intact cells, respectively (fig. $3 \mathrm{c}$ and unpublished data, respectively), which are consistent with published values [30]. A dose response to BDNF generated an $\mathrm{EC}_{50}$ value of $\sim 40 \mathrm{ng} / \mathrm{ml}(1.5 \mathrm{nM})$ in the reporter assay, as demonstrated in figure $3 \mathrm{~d}$. The potency was similar to values obtained in the transient assay (fig. 2b). In addition, these results provided compelling evidence that clone 22 medi- 


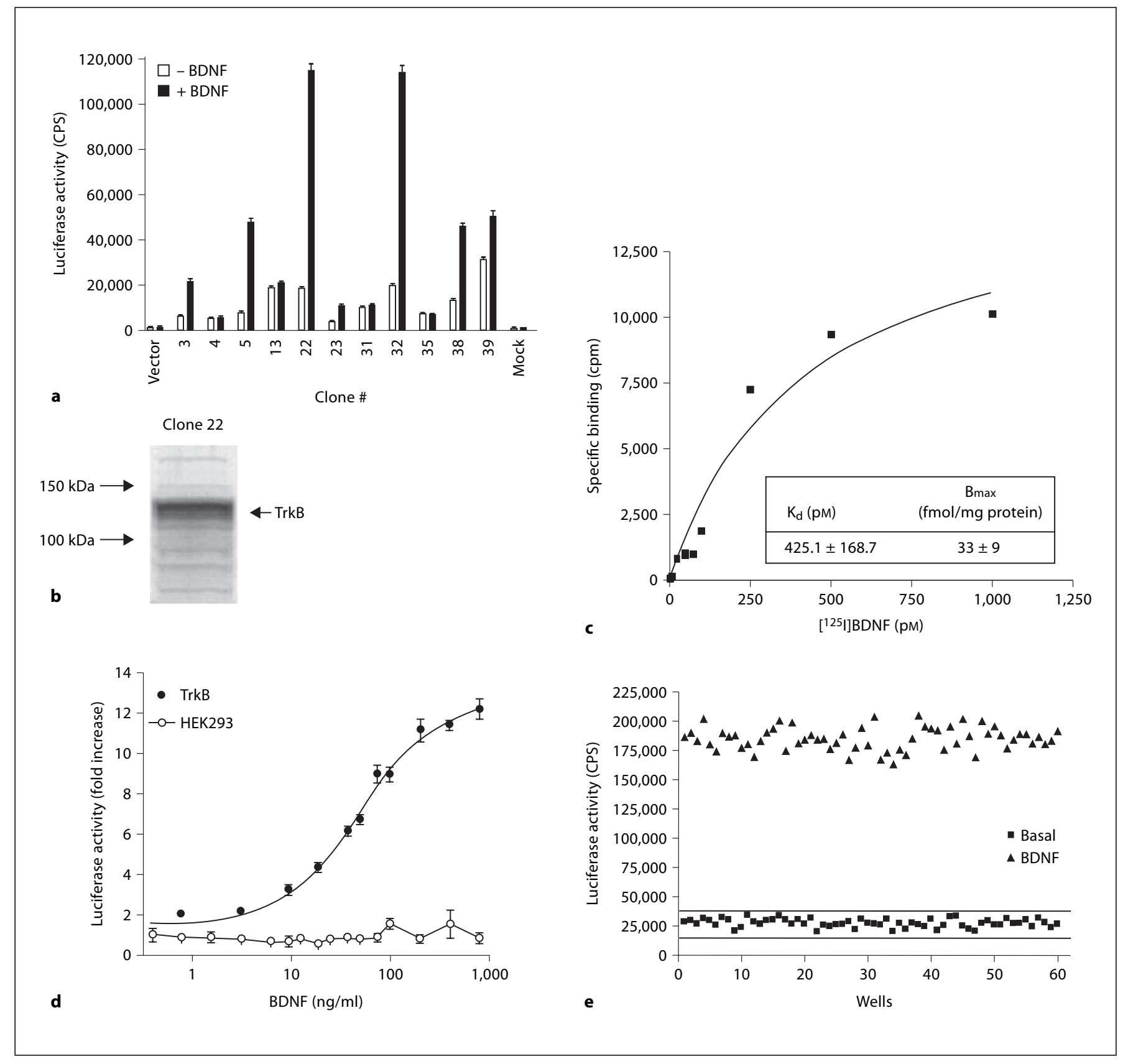

Fig. 3. Characterization of HEK-CRE-TrkB stable cells. a HEKCRE-TrkB stable cell lines were generated and screened for BDNF induction of luciferase responses. Results from 11 of the 39 clones tested in the absence and presence of treatment with $100 \mathrm{ng} / \mathrm{ml}$ BDNF are shown. b Western blot analysis with HEK-CRE-TrkB clone 22 shows a prominent band (arrowhead, TrkB) that migrated with an apparent molecular weight of approximately $140 \mathrm{kDa}$, as estimated from the molecular weight standards (arrows). c Saturation binding curve demonstrating specific binding of $\left[{ }^{125} \mathrm{I}\right] \mathrm{BDNF}$ to the membrane fraction prepared from HEK-CRETrkB clone 22. Binding isotherms obtained from non-linear re-

gression curve-fitting analysis are provided. Calculation of dissociation constants, $K_{d}$, from cell lysates and intact cells indicates the presence of binding sites with affinities similar to previously established ones. $\mathbf{d}$ Luciferase dose-response analysis. The luciferase response following stimulation with increasing concentrations of BDNF to HEK-CRE-TrkB clone 22 gives a sigmoidal curve with an $\mathrm{EC}_{50}$ of $40 \mathrm{ng} / \mathrm{ml}$ (1.5 nM). e Assessment of $Z^{\prime}$ factor. Luciferase activities were measured in three separate 96-well assay plates in the absence and presence of $100 \mathrm{ng} / \mathrm{ml}$ of BDNF and $Z^{\prime}$ factor [31] was calculated $\left(Z^{\prime}\right.$ factor $\left.=0.75\right)$. 
Fig. 4. Luciferase responses of HEK-CRETrkA stable cell lines to NGF treatment. a 27 clonally selected HEK-CRE cells stably transfected with TrkA plasmid were screened for the responsiveness to NGF (100 ng/ml). b NGF dose response of HEKCRE-TrkA clone 24. Data shown represent one of three independent experiments, which all generated similar results.

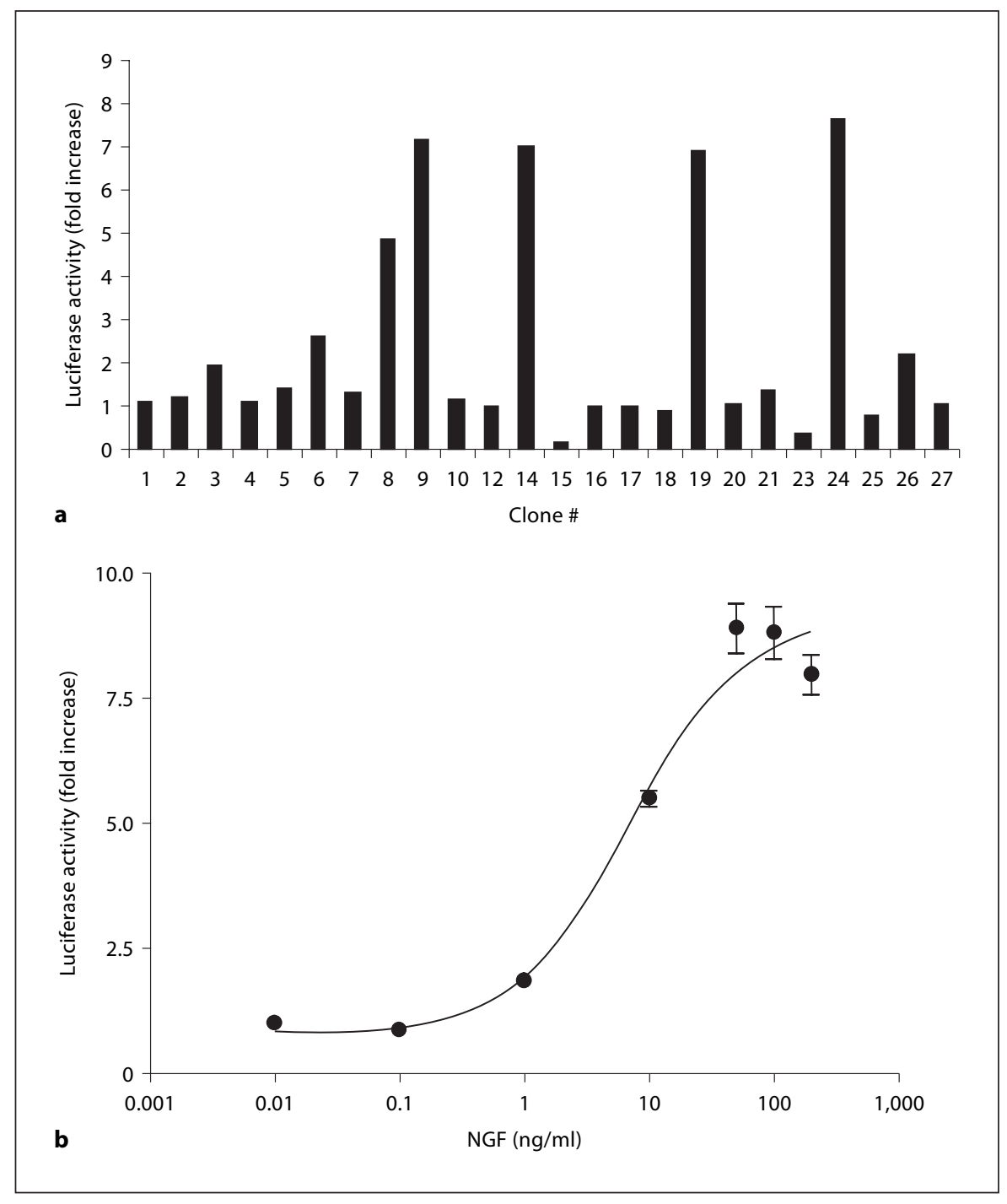

ated a BDNF response through the TrkB receptor at physiologically relevant concentrations. We further assessed the detection sensitivity of the assay using lower concentrations of BDNF and observed that 0.3 and $0.03 \mathrm{ng} / \mathrm{ml}$ $\mathrm{BDNF}$ led to 1.76- and 1.42-fold induction, respectively ( $\mathrm{p}=0.0286$ and 0.001 , respectively), while 1.32 -fold increase by $0.01 \mathrm{ng} / \mathrm{ml}$ BDNF was not statistically different from the basal $(p=0.0938)$. Furthermore, to determine the compatibility of clone 22 for high-capacity screening applications, the signal-to-noise ratios from multiple wells and multiple plates of HEK-CRE-TrkB cells treated in the absence and presence of BDNF were evaluated. The results are provided in figure $3 \mathrm{e}$, where a calculated $\mathrm{Z}$ factor according to Zhang et al. [31] yielded a value of 0.75 , which is within an acceptable range for HTS.
To demonstrate the versatility of this assay system, as well as to develop a counterscreen, we generated stable cell lines expressing TrkA using the same parental cell line. Figure 4 shows specific NGF-induced luciferase activities from representative 27 HEK-CRE-TrkA clones. Again, there was a close correlation between the presence of TrkA-specific band in Western blot analysis and functional luciferase response (data not shown). A dose-response to NGF with clone 24 provided an $\mathrm{EC}_{50}$ of $7 \mathrm{ng} / \mathrm{ml}$ $(0.25 \mathrm{nM})$.

\section{Clone 22 Stable Cells Express Functional TrkB \\ Receptors}

To confirm that the TrkB/BDNF-dependent signal transduction pathway in the neuronal system was reca- 


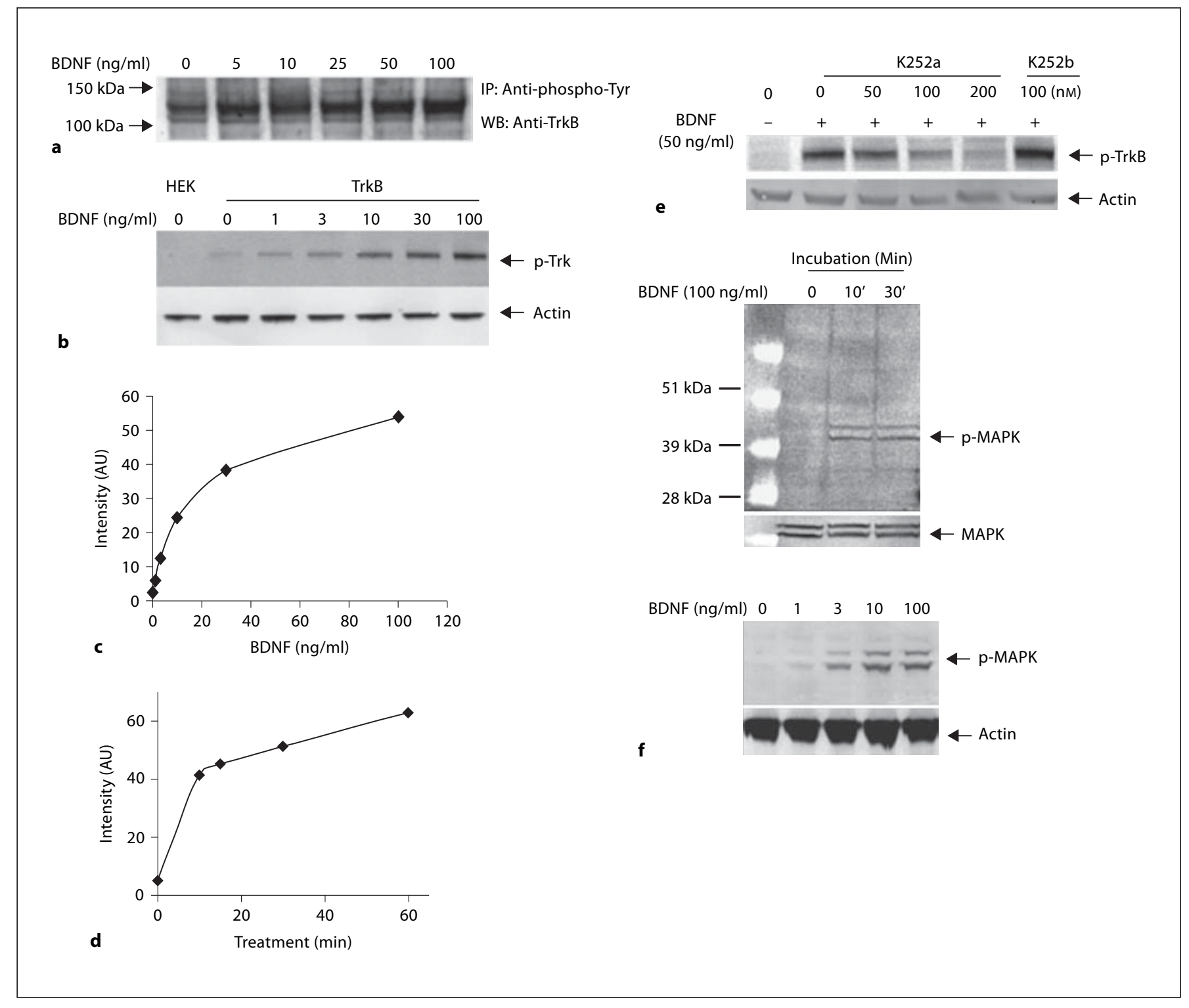

Fig. 5. BDNF induced phosphorylation of TrkB and MAPK in HEK-CRE-TrkB stable cells. a Cells were incubated with the indicated concentrations of BDNF for $1 \mathrm{~h}$ and TrkB phosphorylation was measured by immunoprecipitation (IP) using anti-phosphotyrosine followed by Western blotting (WB) with anti-TrkB antibodies. b TrkB phosphorylation visualized using a phosphoTrk-specific antibody (pY490) (top blot), and compared to signal using anti- $\beta$-actin antibody (bottom blot). c Quantification of the dose-dependent TrkB autophosphorylation presented in $\mathbf{b}$ as a graph of ratio of the signals from matching anti-pTrk and antiactin lanes (Y-axis) as a function of the concentration of BDNF treatment (X-axis). d Time-dependent TrkB phosphorylation. Cells were treated for increasing amount of time $(0,5,1030$, $60 \mathrm{~min}$ ) with $100 \mathrm{ng} / \mathrm{ml}$ of BDNF and processed by WB analysis with an anti-phospho-Trk (pY490) antibody. The band intensity of phosphoTrkB was quantified using a densitometer and graphed as a function of time. e WB analysis demonstrating dose-dependent inhibition of TrkB autophosphorylation by treatments with K252a, but not with K252b. f BDNF-mediated phosphorylation of MAPK in the presence of comparable amounts of total MAPK protein. HEK-CRE-TrkB cells were treated with $100 \mathrm{ng} / \mathrm{ml}$ of BDNF for the indicated times (top panel) or with different BDNF concentrations for $30 \mathrm{~min}$ (bottom panel) and processed for WB analysis with anti-phospho-MAPK antibody, anti-MAPK antibody and anti-actin antibody. Bands for immunoblotted proteins and molecular weight markers are indicated (arrows). Blots shown here are representatives of at least two independent experiments with similar results. 

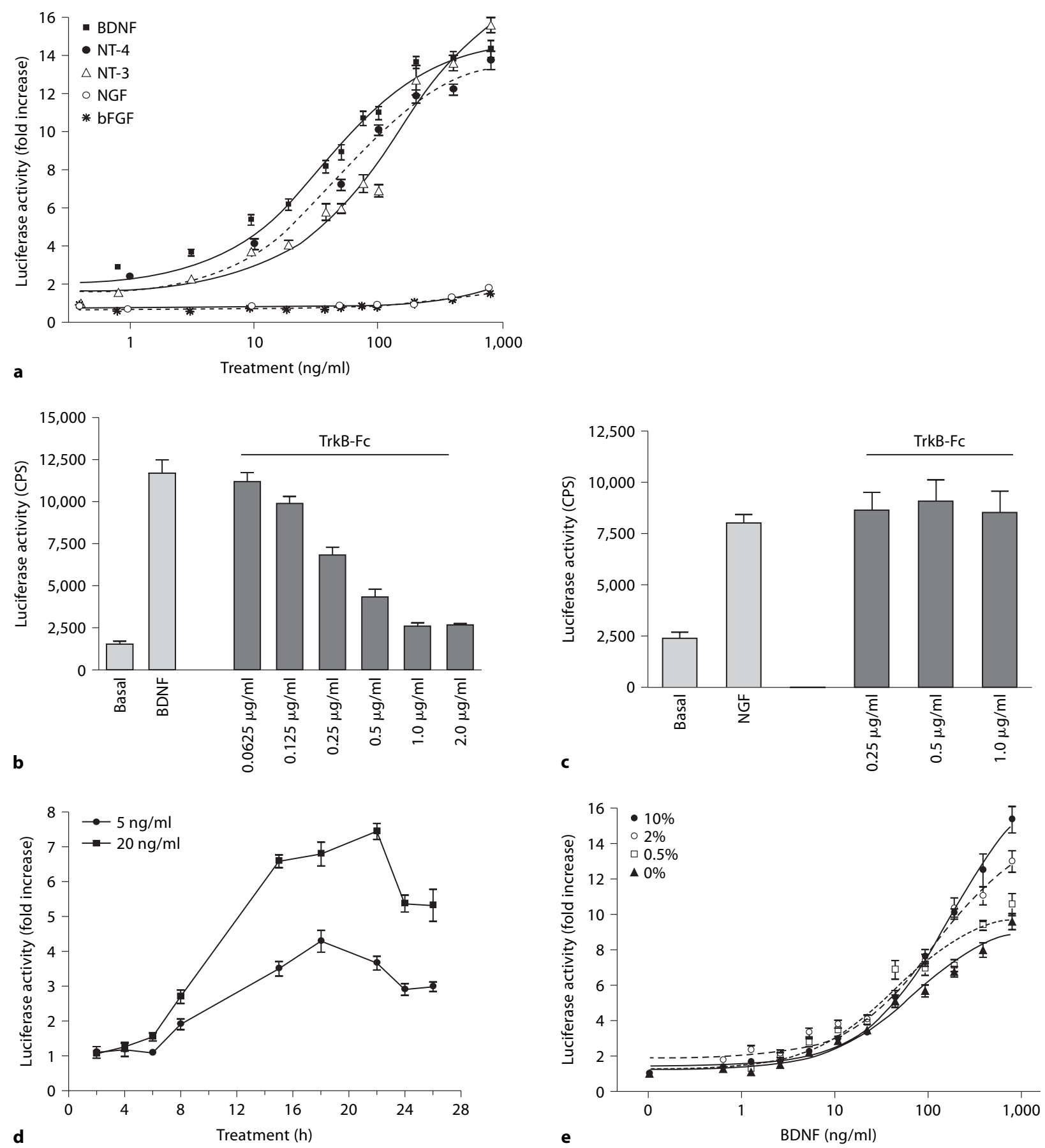

Fig. 6. a Induction of luciferase activities in HEK-CRE-TrkB cells is ligand-specific. HEK-CRE-TrkB clone 22 cells were treated with various trophic factors (BDNF, NGF, NT-4/5, NT-3, and bFGF) for $16 \mathrm{~h}$ and the resultant luciferase activities were measured. Only NT-4/5 demonstrated an $\mathrm{EC}_{50}$ similar to BDNF. b Co-treatment with TrkB-Fc prevented BDNF activation of luciferase. HEK-CRE-TrkB cells were treated with BDNF (100 ng/ml) in the presence of increasing concentrations of TrkB-Fc and the resultant luciferase activities were measured. Addition of TrkB-Fc dose-dependently inhibited the luciferase induction mediated by BDNF. c TrkB-Fc protein had no effects on NGF-mediated luciferase signaling in HEK-CRE-TrkA cells, which were treated as in b except that NGF was substituted for BDNF. d Temporal window of luciferase activity in response to BDNF treatment in HEK- 
pitulated in clone 22, we assessed the phosphorylation of substrates of the TrkB kinase activity using Western blot analysis. Incubation with BDNF induced dose-dependent and time-dependent increases in TrkB autophosphorylation as measured by immunoprecipitation and a direct immunoblot using a phospho-Trk-specific antibody (pY490) (fig. 5a-d). The induction of TrkB phosphorylation was suppressed by treatment with a receptor tyrosine kinase inhibitor, K252a, but not by K252b, indicating the role of a TrkB intracellular tyrosine kinase domain (fig. 5e). In addition, BDNF led to a rapid and denovo phosphorylation of MAPK, while not affecting the total MAPK protein level (fig. 5f). Taken together, these data support the expression of functional TrkB in these cells.

\section{Ligand Specificity and Temporal Patterns of the}

Luciferase Assay

In addition to BDNF, TrkB has been shown to bind NT-4/5 and NT-3. Therefore, we assessed the effects of these NTs in comparison with those of BDNF. As shown in figure $6 \mathrm{a}$, the $\mathrm{EC}_{50} \mathrm{~s}$ of BDNF and NT-4/5 were 40 and $52 \mathrm{ng} / \mathrm{ml}$, respectively, and the $\mathrm{EC}_{50}$ of NT-3 was 3 -fold higher at $141 \mathrm{ng} / \mathrm{ml}$. In contrast, induction of luciferase was undetectable in response to NGF or bFGF (fig. 6a). These results were in complete agreement with functional preference of these NT to TrkB. Neither BDNF nor NT4/5 were effective in eliciting luciferase activity in HEK-CRE parental cells ( $\mathrm{p}<0.05$, unpublished data). To provide additional confirmation that the luciferase responses initiated by BDNF were dependent on TrkB activation, we determined if the addition of a soluble TrkB-Fc fusion protein could block the effect of BDNF. As shown in figure $6 \mathrm{~b}, \mathrm{BDNF}$ resulted in a 8 -fold increase in the luciferase activities, which was dose-dependently inhibited by addition of TrkB-Fc protein $\left(\mathrm{IC}_{50}=0.33 \mu \mathrm{g} / \mathrm{ml}\right.$, $\sim 2.5 \mathrm{nM}$ ). In contrast, TrkB-Fc protein had no effects on NGF-mediated luciferase signaling in TrkA expressing cells (fig. 6c).

The temporal window of luciferase activities was assessed at various time points after BDNF addition. Con-

CRE-TrkB cells. Luciferase activities were assessed at different time points after BDNF addition. e The effect of serum in the luciferase activities. To assess whether the presence of serum alters the BDNF-mediated luciferase responses, cells were incubated with BDNF in culture media containing varying concentrations of serum and the luciferase activities were measured as in the Materials and Methods.

Cyclic-AMP Response Element-Based Signaling Assays sistent with transient expression, the induction of the luciferase activities was minimal up to $6 \mathrm{~h}$, after which it gradually increased and the activity peaked between 16 and $22 \mathrm{~h}$ (fig. 6d). Accordingly, most of our assays in the study were performed at $16 \mathrm{~h}$ of BDNF incubation. This result showed that the signaling modulation and the luciferase readout were temporally quite stable, which should facilitate the transfer of the assay to a routine screening procedure. We also examined the effects of different concentrations of serum on the response sensitivity (fig. 6e). Comparing a normal 10\% serum-containing growing condition with a $2 \%$ serum composition, there was a slight reduction in the maximum signal window detected in the cells maintained in $2 \%$ serum (12-fold increase in $2 \%$ vs. 15 -fold increase in $10 \%$ serum condition). $\mathrm{EC}_{50}$ values, however, were not affected by either assay condition. Furthermore, good signal separation was observed even with $0.5 \%$ or no serum-containing conditions with comparable $\mathrm{EC}_{50}$ values $(33$ and $47 \mathrm{ng} / \mathrm{ml}$ for $0.5 \%$ and no serum conditions, respectively), suggesting that lower serum conditions could be used in a compound screening assay thus removing artifacts caused by serum binding as well as substantially reducing reagent costs.

\section{Pharmacological Characterization of the TrkB \\ Luciferase Assay}

The signals of TrkB activation are known to be transduced via intracellular signaling cascades involving mitogen-activated kinase (ERK), PI3K/Akt and PLC- $\gamma$ pathways [32] (fig. 1). Therefore, we assessed whether the pharmacological inhibitors of these pathways would lead to the reduction of the luciferase activity initiated by BDNF. Pretreatment with wortmannin, a PI3K inhibitor, U73122, a PLC- $\gamma$ inhibitor, and thapsigargin effectively antagonized the effects of BDNF, resulting in a complete blockade of luciferase signals (fig. 7a), while U73343, an inactive analogue of U73122, at 1 and $10 \mu \mathrm{M}$ did not have any effects $(p>0.05)$. Wortmannin and U73122 had no effects on the basal luciferase activity $(1.09 \pm 0.05$ - and $1.00 \pm 0.24$-fold induction with $5 \mu \mathrm{M}$ wortmannin and U73122, respectively, over vehicle-treated cells) whereas treatment with thapsigargin resulted in slight increase of the signal in the absence of BDNF (1.44 \pm 0.1- and 1.51 \pm 0.11 -fold induction by 0.5 and $2 \mu \mathrm{M}$, respectively). On the other hand, treatment with $\mathrm{K} 252 \mathrm{a}$ resulted in a Ushape response with a partial inhibition only and subsequent potentiation of BDNF signals at high concentrations of K252a (fig. 7b). Interestingly, at these high concentrations, K252a increased luciferase signals by itself in the absence of BDNF (fig. 7b), suggesting non-specific 


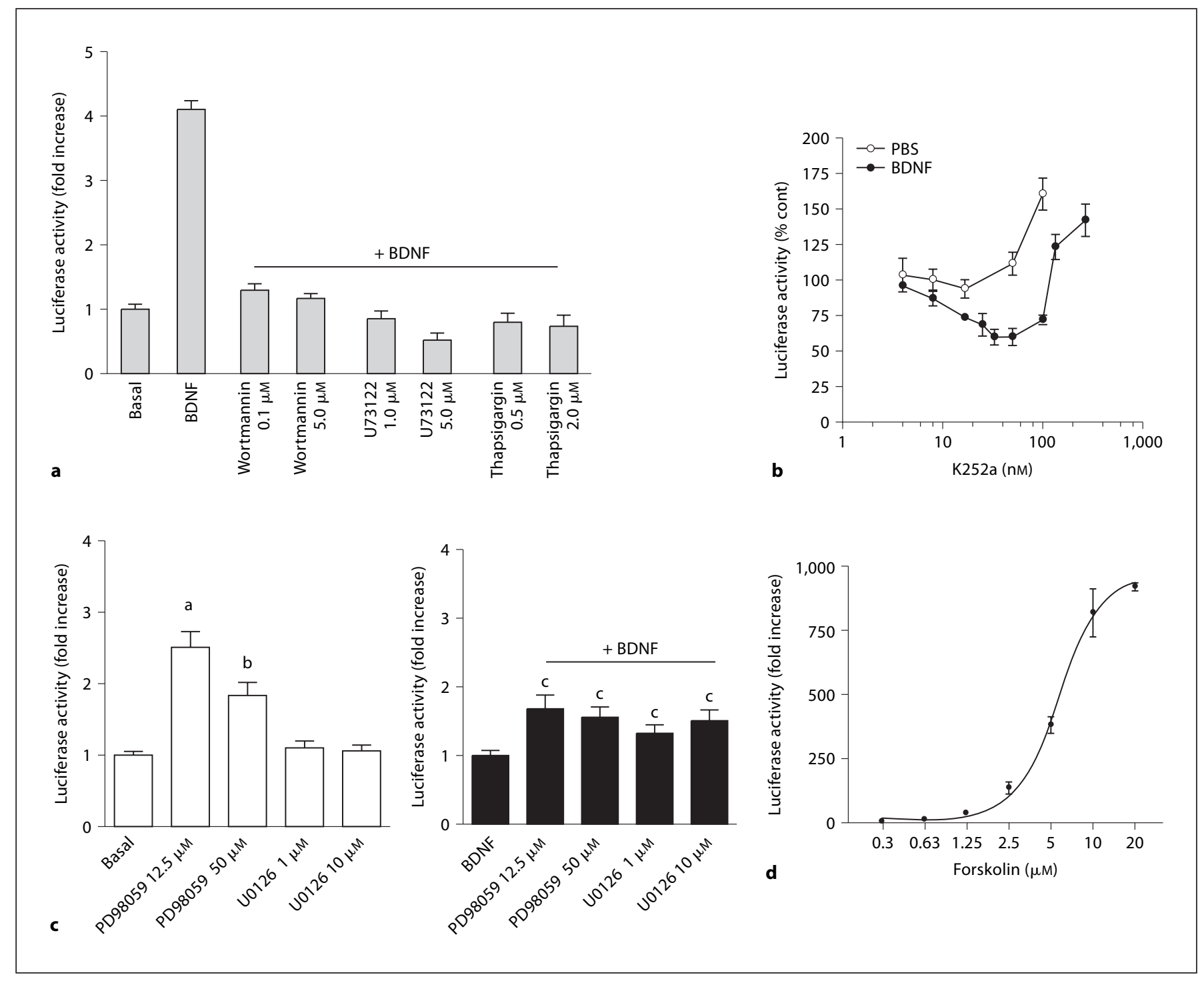

Fig. 7. Pharmacological characterization of the luciferase assay in HEK-CRE-TrkB cells. a HEK-CRE-TrkB cells were treated with wortmannin, U73122 or thapsigargin for $15 \mathrm{~min}$ at indicated concentrations followed by addition of $100 \mathrm{ng} / \mathrm{ml}$ of BDNF and luciferase activities were measured. Cells treated in the absence and presence of BDNF were also included. b Dose-dependent effects of K252a. HEK-CRE-TrkB cells were incubated with increasing concentrations of $\mathrm{K} 252 \mathrm{a}$ and $15 \mathrm{~min}$ later treated or not with $50 \mathrm{ng} / \mathrm{ml}$ of BDNF before being processed for the luciferase activity. c Effects of ERK/MEK kinase inhibitors PD98059 or U0126 on BDNF-mediated luciferase activity in HEK-CRE-TrkB cells. Cells were pretreated in the absence and presence of inhibitors and then treated in the absence and presence of $100 \mathrm{ng} / \mathrm{ml}$ of BDNF before being assayed for luciferase activities. ${ }^{a} \mathrm{p}<0.01 \mathrm{vs.}$ basal; ${ }^{\mathrm{b}} \mathrm{p}<0.05 \mathrm{vs}$. basal; ${ }^{\mathrm{c}} \mathrm{p}<0.01 \mathrm{vs}$. BDNF alone (t test). $\mathrm{d}$ Dosedependent activation of the luciferase reporter activities by forskolin. HEK-CRE-TrkB cells were treated with varying concentrations of forskolin and the luciferase activities were determined next day. $\mathrm{EC}_{50}=5.7 \mu \mathrm{M}$. inhibition of other kinases independent of TrkB. Treatment with PD98059 and U0126, inhibitors of MEK, which had marginal activities on their own, further increased the luciferase activities in all doses tested when combined with BDNF (fig. 7c). In a subsequent experiment, we also examined the response of compounds that directly affect signal transduction involved in CREB phosphorylation. For example, forskolin, a protein kinase A activator, induced dose-dependent increases of CREB activities in both parental and HEK-CRE-TrkB cell lines (fig. $7 \mathrm{~d}$ and 
unpublished data). The dose responses were similar in both cell lines generating $\mathrm{EC}_{50}$ values of 6.4 and $6.0 \mu \mathrm{M}$ in HEK-CRE and HEK-CRE-TrkB cells, respectively. Similarly, we also observed robust dose-dependent luciferase induction by phorbol 12-myristate-acetate (PMA) in both cell lines ( 9 and 11.8 maximum fold induction over the basal in HEK-CRE and HEK-CRE-TrkB cells, respectively).

\section{Discussion}

Potential therapeutic utilities of $\operatorname{TrkB}$ agonists are widely reported in various experimental models of human diseases, yet there is no effective drug available in the clinic that directly modulates these systems. From a drug discovery perspective, this provides tremendous opportunities in which one could explore the molecular determinants of the receptor in affecting intracellular activities and lead to a development of a first-in-class therapy where no treatments exist. While full-length NT dimers appear to activate Trk receptors by inducing dimerization, the structural evidence depicting the limited number of spatially restricted contact sites between NT and Trk $[6,33]$ supports the argument that a small molecule could span the distance necessary to homodimerize the Trk receptors. Precedent for this mode of action may be provided by SB-247464, a small non-peptide compound that displays high specificity and potency for the G-CSF receptor [25]. The biological activity of SB-247464 is indistinguishable from that of the natural ligand, GCSF, which is 120 amino acid cytokine. That the structure of SB-247464 contains 2-fold rotational symmetry suggests that its agonist activity might be mediated by dimerization of the G-CSF receptor [25].

The aim in this report was to develop a sensitive and simple functional assay to measure Trk activation, which can be implemented in compound screening. We chose TrkB as a prototype of all the NT receptors to validate the assay. As illustrated in figure 1, activation of TrkB is propagated through multiple intracellular signal transduction cascades, which may converge to phosphorylate CREB and induce CRE-dependent transcriptional regulation. CRE-dependent activities have been shown to be important for NT-dependent neuronal survival and synaptic plasticity $[19,34]$. Since we had an available CRE-luciferase reporter gene stably expressed in HEK293 cells, we evaluated this system. Transient transfection of TrkB in HEK-CRE cells resulted in a time- and dose-dependent accumulation of a luciferase signal in response to BDNF.
The temporal analysis revealed an initial lag period followed by a gradual increase in the signal, consistent with the luciferase accumulation resulting from induction of transcription. The sensitivity to BDNF and robustness of the signal suggest that this system may be used to analyze the mechanism of BDNF action, including the identification of small molecular weight compounds. However, the distinctive temporal profiles between the receptor activation (in minutes) and reporter activities (in hours) have to be taken into consideration in evaluating the activity of screening compounds, since the compounds' properties such as stability and toxicity could affect the apparent outcome in the reporter activities. Importantly, the protracted incubation time required to attain luciferase signals may select out compounds that are rapidly deactivated or promote toxicity. As our interest is to identify compounds that regulate long-range effects, such as neuroprotection and regeneration, this assay should filter out undesirable compounds.

To permit a thorough analysis, including the possibility of high-throughput screening of small molecules, we produced Trk receptor stable cell lines. One line (HEKCRE-TrkB clone 22) was chosen for further characterization. We confirmed the expression of TrkB by the migration in Western blots of a band consistent with the apparent molecular weight of full-length TrkB. Radioligand binding studies indicated that $\operatorname{TrkB}$ had a sub-nanomolar affinity for $\left[{ }^{125} \mathrm{I}\right] \mathrm{BDNF}$ consistent with reported values [30] and a higher density of binding sites than expressed in native tissues [35]. In the luciferase assay, BDNF was highly potent, induced a robust signal, and yielded a $\mathrm{Z}$ factor suitable for HTS assay [31]. To directly measure TrkB activation, BDNF-induced autophosphorylation of TrkB was examined. By Western blot analysis, autophosphorylation was significantly inhibited with a selective tyrosine kinase inhibitor K252a. The ranges of effective BDNF doses in both the luciferase assay and for autophosphorylation resulted in comparable $\mathrm{EC}_{50}$ values, which concur with published physiological BDNF concentrations tested in neuronal cultures $[29,36]$. In the luciferase assay, the rank order potency for TrkB agonists was BDNF $=\mathrm{NT}-4 / 5$ $>$ NT-3 and NGF and bFGF were inactive. Alternatively, NGF was highly potent in inducing luciferase activity in a HEK-CRE-TrkA cell line. These results showed that the HEK-CRE cells provided a suitable cell line for high-level expression of Trk receptors.

In another set of experiments, we co-treated HEKCRE-Trk cells with soluble TrkB-Fc proteins and cognate $\mathrm{NT}$ and monitored the luciferase response. We observed that TrkB-Fcled to a dose-dependent inhibition of BDNF- 
induced luciferase response in HEK-CRE-TrkB but not of NGF-induced luciferase signal in HEK-CRE-TrkA cells. These results conferred two notions: first, they provided sound evidence on the selectivity of the assay toward TrkB, and second, demonstrated that the assay could also be used to identify selective Trk receptor antagonists, in addition to agonists.

CREB-mediated luciferase transcription is regulated via activation of several intracellular enzymatic pathways downstream of TrkB. As anticipated, treatments of BDNFstimulated HEK-CRE-TrkB cells with pharmacological inhibitors of these pathways such as wortmannin (inhibits PI3K), thapsigargin (inhibits intracellular calcium pumps), and U73122 (inhibits PLC- $\gamma$ ) resulted in marked reduction of the luciferase readouts. It is important to note that these inhibitors did not simply quench a luciferase signal, as the addition of these inhibitors after the luciferase signal had accumulated did not affect the responses (data not shown). Treatments with K252a, a receptor tyrosine kinase inhibitor, resulted in a $\mathrm{U}$-shape curve, with maximal inhibition occurring at $20 \mathrm{nM}$, and potentiation of the BDNF response at higher concentrations $(>100 \mathrm{nM})$. We speculated that K252a at high concentrations lost its selectivity $\left(\mathrm{IC}_{50} \mathrm{~s}\right.$ of $10-30 \mathrm{nM}$ [37]) and consequently raised luciferase signals presumably via altering the phosphorylation status of other proteins independent of $\operatorname{TrkB}[38,39]$, which may warrant further confirmation. A biphasic dose-response has been reported for the ability of K252a to potentiate the NT-3 action on cholinergic neurons and a similar inverted U-shaped curve has been observed with a structural analogue K252b [40]. Finally, treatment with two MEK1 inhibitors (PD98059 and U0126) potentiated the BDNF-induced luciferase signals. The concentrations of these inhibitors used in the study were chosen based on the literature information $[29,41$, 42] and were expected to completely inhibit MEK1, although we have not confirmed this independently. It is therefore presumed that in our cellular context these inhibitors modulated other substrates in addition to MEK1, such as other kinases/phosphatases, which directly or in- directly elevated the BDNF response. This notion is consistent with our observation that PD98059 by itself could increase luciferase signals in the absence of BDNF. A thorough time dependent study may detect MAPK-mediated modulation of CRE activities. Alternatively, it cannot be excluded that BDNF-mediated CREB signaling in our assay is MAPK pathway-insensitive.

While our data validate the assay system as an effective screen for TrkB activity, it needs to be kept in mind that the CRE-mediated reporter activity can also be influenced by compounds that directly affect phosphorylation status of several intracellular kinase cascades, independent of TrkB. It is well exemplified in the study with forskolin and PMA, which induced significant increases in the luciferase activity in both control and TrkB cells. Therefore in order to identify Trk-selective agonists, it is critical to incorporate multiple control experiments to sieve out off-target compounds. To this end, we have established TrkA-expressing cells as well as a parental control clone, which contain the same machinery leading to CRE signaling as the TrkB cell line, while not responding to BDNF. Cross-comparison in these cell systems, therefore, should allow differentiation of potential TrkB agonists from false-positive compounds.

In conclusion, we have developed a highly sensitive and homogenous reporter assay for Trk receptors, which could be implemented in high-throughput format for the screening of compound libraries. Combined with welldesigned counterscreening as well as binding and structural analyses, this assay system may provide a powerful approach to identify hits and facilitate early lead optimization of small molecular weight compounds that modulate Trk receptors.

\section{Acknowledgments}

The authors thank Stanley Nawoschik for providing HEKCRE cells and Dr. Mark Pausch for a critical reading of the manuscript.

\section{References}

1 Friedman WJ, Greene LA: Neurotrophin signaling via Trks and p75. Exp Cell Res 1999;253:131-142.

$\checkmark 2$ Hempstead BL: The many faces of p75NTR. Curr Opin Neurobiol 2002;12:260-267.
3 Connor B, Dragunow M: The role of neuronal growth factors in neurodegenerative disorders of the human brain. Brain Res Rev 1998;27:1-39.
-4 Klein R, Nanduri V, Jing SA, Lamballe F, Tapley P, Bryant S, Cordon-Cardo C, Jones KR, Reichardt LF, Barbacid M: The trkB tyrosine protein kinase is a receptor for brainderived neurotrophic factor and neurotrophin-3. Cell 1991;66:395-403. 
5 Clary DO, Reichardt LF: An alternatively spliced form of the nerve growth factor receptor TrkA confers an enhanced response to neurotrophin 3. Proc Natl Acad Sci USA 1994;91:11133-11137.

6 O'Leary PD, Hughes RA: Design of potent peptide mimetics of brain-derived neurotrophic factor. J Biol Chem 2003;278:2573825744.

7 Banfield MJ, Naylor RL, Robertson AGS, Allen SJ, Dawbarn D, Brady RL: Specificity in Trk receptor:neurotrophin interactions: the crystal structure of TrkB-d5 in complex with neurotrophin-4/5. Structure 2001;9:11911199.

$>8$ Ibanez CF, Ilag LL, Murray-Rust J, Persson $\mathrm{H}$ : An extended surface of binding to Trk tyrosine kinase receptors in NGF and BDNF allows the engineering of a multifunctional pan-neurotrophin. EMBO J 1993;12:22812293.

$\checkmark 9$ Zaccaro MC, Lee HB, Pattarawarapan M, Xia Z, Caron A, L'Heureux PJ, Bengio Y, Burgess K, Saragovi HU: Selective small molecule peptidomimetic ligands of TrkC and TrkA receptors afford discrete or complete neurotrophic activities. Chem Biol 2005;12:10151028.

10 Williams G, Williams EJ, Maison P, Pangalos MN, Walsh FS, Doherty P: Overcoming the inhibitors of myelin with a novel neurotrophin strategy. JBiol Chem 2005;280:58625869.

11 Huang EJ, Reichardt LF: Trk receptors: roles in neuronal signal transduction. Annu Rev Biochem 2003;72:609-642.

-12 Mischel PS, Umbach JA, Eskandari S, Smith SG, Gundersen CB, Zampighi GA: Nerve growth factor signals via preexisting TrkA receptor oligomers. Biophys J 2002;83:968976.

-13 Pattarawarapan M, Burgess K: Molecular basis of neurotrophin-receptor interactions. J Med Chem 2003;46:5277-5291.

-14 Encinas M, Iglesias M, Llecha N, Comella JX: Extracellular-regulated kinases and phosphatidylinositol 3-kinase are involved in brain-derived neurotrophic factor-mediated survival and neuritogenesis of the neuroblastoma cell line SH-SY5Y. J Neurochem 1999;73:1409-1421.

-15 Yuen EC, Mobley WC: Early BDNF, NT-3, and NT-4 signaling events. Exp Neurol 1999;159:297-308.

-16 Skaper SD, Floreani M, Negro A, Facci L, Giusti P: Neurotrophins rescue cerebellar granule neurons from oxidative stress-mediated apoptotic death: selective involvement of phosphatidylinositol 3-kinase and the mitogen-activated protein kinase pathway. J Neurochem 1998;70:1859-1868.

-17 Finkbeiner S, Tavazoie SF, Maloratsky A, Jacobs KM, Harris KM, Greenberg ME: CREB: a major mediator of neuronal neurotrophin responses. Neuron 1997;19:1031-1047.
18 Simon J, Arthur C, Fong AL, Dwyer JM, Davare M, Reese E, Obrietan K, Impey S: Mitogen- and stress-activated protein kinase 1 mediates cAMP response element-binding protein phosphorylation and activation by neurotrophin. J Neurosci 2004;24:43244332.

19 Ernfors P, Bramham CR: The coupling of a trkB tyrosine residue to LTP. Trends Neurosci 2003;26:171-173.

20 Miller SG: Discovery of cytokine mimics using cell-based systems. Drug Discov Today 2000; 5(suppl 1):77-83.

21 Angeles TS, Lippy JS, Yang SX: Quantitative, high-throughput cell-based assays for inhibitors of trkA receptor. Anal Biochem 2000;278:93-98.

22 Bohmer FD, Bohmer A, Obermeier A, Ullrich A: Use of selective tyrosine kinase blockers to monitor growth factor receptor dephosphorylation in intact cells. Anal Biochem 1995; 228:267-273.

23 Zhang B, Salituro G, Szalkowski D, Li Z Zhang Y, Royo I, Vilella D, Diez MT, Pelaez F, Ruby C, Kendall RL, Mao X, Griffin P, Calaycay J, Zierath JR, Heck JV, Smith RG, Moller DE: Discovery of a small molecule insulin mimetic with antidiabetic activity in mice. Science 1999;284:974-977.

24 Remy I, Michnick SW: Clonal selection and in vivo quantitation of protein interactions with protein-fragment complementation assays. Proc Natl Acad Sci USA 1999;96:53945399.

25 Tian SS, Lamb P, King AG, Miller SG, Kessler L, Luengo JI, Averill L, Johnson RK, Gleason JG, Pelus LM, Dillon SB, Rosen J: A small, nonpeptidyl mimic of granulocyte-colonystimulating factor. Science 1998;281:257259.

-26 Williams AG, Hargreaves AC, Gunn-Moore FJ, Tavare JM: Stimulation of neuropeptide Y gene expression by brain-derived neurotrophic factor requires both the phospholipase Cgamma and Shc binding sites on its receptor, TrkB. Biochem J 1998;333:505509.

27 Maliartchouk S, Feng Y, Ivanisevic L, Debeir T, Cuello AC, Burgess K, Saragovi HU: A designed peptidomimetic agonistic ligand of TrkA nerve growth factor receptors. Mol Pharmacol 2000;57:385-391.

28 Kojima S, Nakayama T, Kuwajima G, Suzuki $\mathrm{H}$, Sakata T: TrkB mutant lacking the amino-terminal half of the extracellular portion acts as a functional brain-derived neurotrophic factor receptor. Biochim Biophys Acta 1999;1420:104-110.

29 Hetman M, Kanning K, Cavanaugh JE, Xia Z: Neuroprotection by brain-derived neurotrophic factor is mediated by extracellular signal-regulated kinase and phosphatidylinositol 3-kinase. J Biol Chem 1999;274:2256922580 .
30 Naylor RL, Robertson AGS, Allen SJ, Sessions RB, Clarke AR, Mason GGF, Burston JJ, Tyler SJ, Wilcock GK, Dawbarn D: A discrete domain of the human TrkB receptor defines the binding sites for BDNF and NT-4. Biochem Biophys Res Commun 2002;291:501507.

31 Zhang JH, Chung TD, Oldenburg KR: A simple statistical parameter for use in evaluation and validation of high throughput screening assays. J Biomol Screen 1999;4:67-73.

32 Kaplan DR, Miller FD: Neurotrophin signal transduction in the nervous system. Curr Opin Neurobiol 2000;10:381-391.

33 Wiesmann C, Ultsch MH, Bass SH, de Vos AM: Crystal structure of nerve growth factor in complex with the ligand-binding domain of the TrkA receptor. Nature 1999;401:184188 .

34 Finkbeiner S: CREB: a major mediator of neuronal neurotrophin responses. Neuron 2000;25:11-14.

35 Rodriguez-Tebar A, Barde YA: Binding characteristics of brain-derived neurotrophic factor to its receptors on neurons from the chick embryo. J Neurosci 1988;8:33373342.

36 Yamagishi S, Matsumoto T, Yokomaku D, Hatanaka H, Shimoke K, Yamada M, Ikeuchi T: Comparison of inhibitory effects of brainderived neurotrophic factor and insulin-like growth factor on low potassium-induced apoptosis and activation of p38 MAPK and c-Jun in cultured cerebellar granule neurons. Brain Res Mol Brain Res 2003;119:184-191.

37 Tapley P, Lamballe F, Barbacid M: K252a is a selective inhibitor of the tyrosine protein kinase activity of the trk family of oncogenes and neurotrophin receptors. Oncogene 1992; 7:371-381.

38 Wu CF, Zhang M, Howard BD: K252a potentiates epidermal growth factor-induced differentiation of PC12 cells. J Neurosci Res 1993;36:539-550.

39 Maroney AC, Lipfert L, Forbes ME, Glicksman MA, Neff NT, Siman R, Dionne CA: $\mathrm{K}-252 \mathrm{a}$ induces tyrosine phosphorylation of the focal adhesion kinase and neurite outgrowth in human neuroblastoma SH-SY5Y cells. J Neurochem 1995;64:540-549.

40 Knusel B, Kaplan DR, Winslow JW, Rosenthal A, Burton LE, Beck KD, Rabin S, Nikolics K, Hefti F: K-252b selectively potentiates cellular actions and trk tyrosine phosphorylation mediated by neurotrophin-3. J Neurochem 1992;59:715-722.

41 Zheng WH, Quirion R: Comparative signaling pathways of insulin-like growth factor-1 and brain-derived neurotrophic factor in hippocampal neurons and the role of the PI3 kinase pathway in cell survival. J Neurochem 2004;89:844-852.

-42 Koyama Y, Tsujikawa K, Matsuda T, Baba A: Endothelin-1 stimulates glial cell line-derived neurotrophic factor expression in cultured rat astrocytes. Biochem Biophys Res Commun 2003;303:1101-1105. 